\title{
DIFFERENTIATION OF ACTIVELY AND PASSIVELY ACQUIRED COMPLEMENT-FIXING ANTIBODIES IN INFANTS WITH RESPIRATORY SYNCYTIAL VIRUS INFECTION
}

\author{
J. W. JaCoBs* and D. B. PeACOCK \\ Department of Bacteriology, Medical School, University Walk, \\ Bristol
}

Although it has been suggested that infants under the age of $4 \mathrm{mth}$ do not form complement-fixing (CF) antibodies after infection with respiratory syncytial (RS) virus (Wulff, Kidd and Wenner, 1964), it is more likely that such antibodies as are produced have a higher antigen requirement than the corresponding antibodies produced by adults (Chanock et al., 1961; Kapikian et al., 1961). The latter two groups of workers used twice as much antigen as was required for fixation with adult sera and found that the rate of serodiagnosis in infants was doubled, the CF test then being as sensitive as the neutralisation test (Kapikian et al.) though still only half as sensitive as virus isolation (Chanock et al., 1961). Ross et al. (1964) used more potent antigens and showed that infants' sera had antibody titres comparable with those of adults' sera, but that about eight times as much antigen was required for optimal complement fixation with the infants' sera. Under these conditions the CF test might become the most sensitive method for the diagnosis of RS virus infections.

However, infection often occurs in infants despite the presence of maternal antibody, and in such cases there may be no significant rise in CF antibody levels between acute and convalescent serum samples, or even a fall. Thus, in infants less than $4 \mathrm{mth}$ old, who frequently possess maternal antibody, a fourfold rise in antibody titre is an insensitive indication of infection (Chanock et al., 1961; Parrott et al., 1961).

We now present evidence that it is possible to distinguish between actively and passively acquired antibodies in infants' sera on the basis of their fixation patterns in the CF test, and therefore to increase the sensitivity of the test in the very young.

\section{MATERIALS AND METHODS}

$R S$ virus antigens. The preparation of $\mathrm{CF}$ antigens of the necessary potency from RS virus has been described elsewhere (Jacobs, 1968).

Human sera. Acute-phase sera were obtained from infants with acute respiratory infections on or soon after their admission to one of two Bristol hospitals between 1965 and 1967. Convalescent-phase sera were taken 4-6 wk later, in accordance with the recommendation of Ross et al. (1964). Sera were also obtained from mothers of these infants, and those with high anti-RS virus CF titres were pooled to provide a " standard antiserum".

Received 26 Aug. 1969; accepted 4 Nov. 1969.

* Present address: Department of Pathology, The Royal Veterinary College, Royal College Street, London, N.W.1.

J. MED. MICROBIOL.-VOL. 3 (1970) 
Complement-fixation test. The "Microtiter" system was used as previously described (Jacobs, 1968), the plates being mechanically shaken during the lytic stage of the test (Jacobs, 1969). Results of the block titrations are expressed as complement contours (Fulton, 1958), with fixation of $1 \frac{1}{2}$ MHD50 of complement. The unit of antigen is defined as the smallest amount that gives the highest titre with the "standard antiserum" in the CF test. All the antigen preparations showed a peak-rather than a plateau-pattern of fixation (Grist et al., 1966), so that the unit of antigen in fact represented an optimal dilution of antigen.

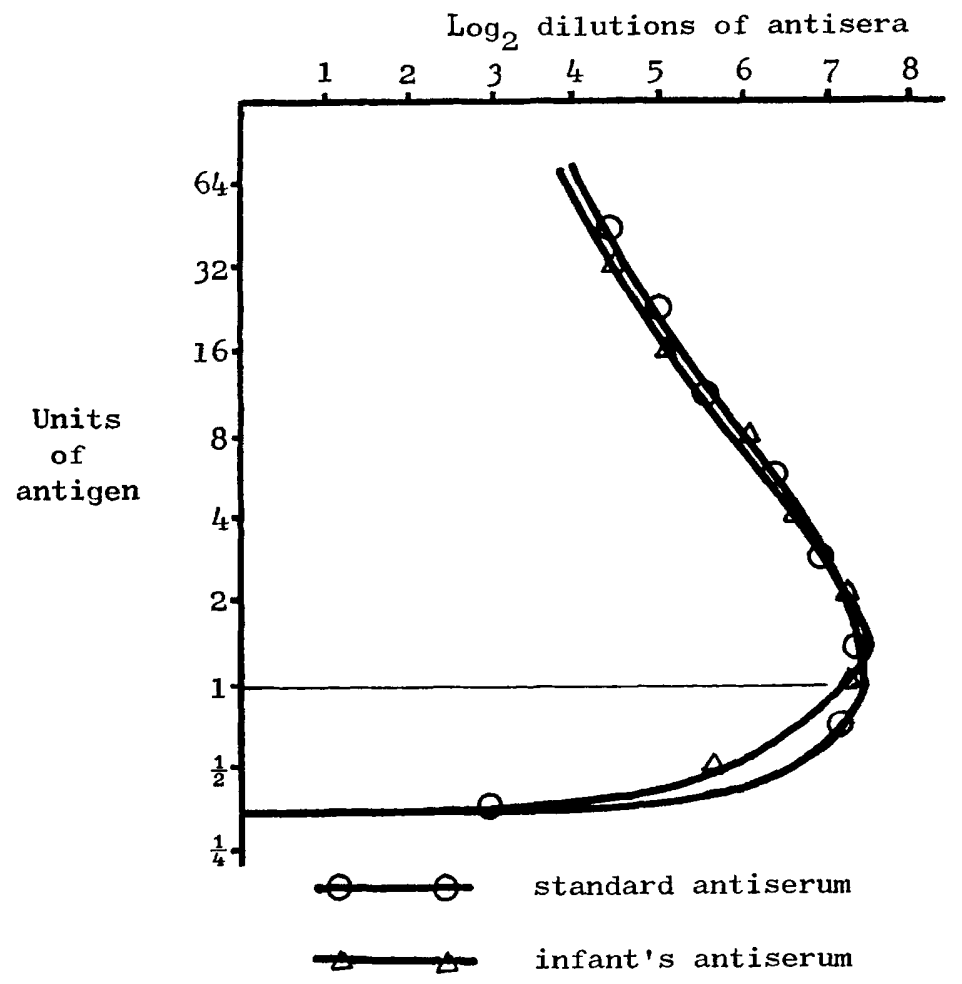

FIG. 1.-Fixation patterns with the standard antiserum and with an infant's serum containing passively acquired antibody.

Density gradient centrifugation. The technique of Vesikari and Vaheri (1968) was used with some modification; $0.2 \mathrm{ml}$ of serum was layered on top of a linear sucrose gradient (37 per cent. to 12.5 per cent.) made up in CF diluent; after centrifugation at $100,000 \mathrm{~g}$ for $14 \frac{1}{2}-15 \frac{1}{2} \mathrm{hr}$ in an MSE $3 \times 3 \mathrm{ml}$ rotor, fractions were collected dropwise from each tube and tested for CF antibody activity.

\section{ResulTs \\ Passively acquired antibody}

The fixation patterns of the standard antiserum and several acute-phase infants' sera were compared. The infants were less than $1 \mathrm{mth}$ old and presented no history of previous RS virus infection, but their sera contained high titres of $\mathrm{CF}$ antibody to RS virus, presumably maternal in origin. The results of one 
such comparison are shown in fig. 1, the pattern being typical of all the infants' sera tested.

It can be seen that the fixation patterns are very similar, and most of the other sera in this group also showed optimal fixation with $1-1 \frac{1}{2}$ units of antigen. None required less than 1 unit, and it was concluded that the range of antigen optima was 1-2 units.

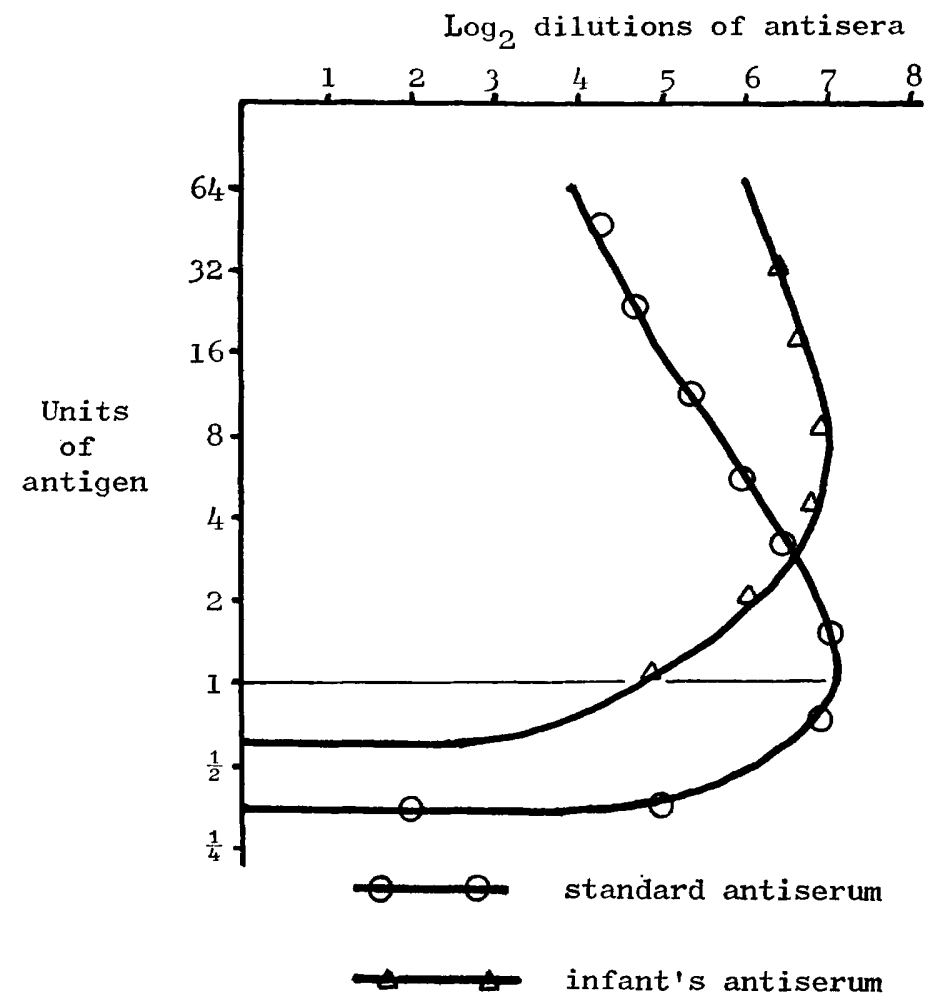

Fig. 2.-Fixation patterns with the standard antiserum and with an infant's antiserum containing active antibody.

\section{Actively acquired antibody}

The fixation patterns of the standard antiserum and several convalescentphase infants' sera were compared. The infants were more than $4 \mathrm{mth}$ old and were recovering from RS virus infections. A typical result is shown in fig. 2.

It can be seen that this infant's serum gave a fixation pattern that differs considerably from that of the standard antiserum. Despite the range of ages of the infants tested, their fixation patterns were all similar, and it was concluded that optimal fixation with actively acquired antibody occurred with 4-8 units of antigen.

In addition, inspection of fig. 2 shows that the minimum amount of antigen detectable by serum from either source was similar. Such maximum titres of 
antigen were obtained only with high-titred infants' sera, and in these circumstances the ratio of maximum to optimum antigen titre was 8-16, compared with the ratio of 3 obtained with "standard antiserum ".

\section{Differentiation of antibody in paired sera from infants}

The above results suggested that active and passive immunity in infants could be distinguished on the basis of the fixation patterns of serum antibodies

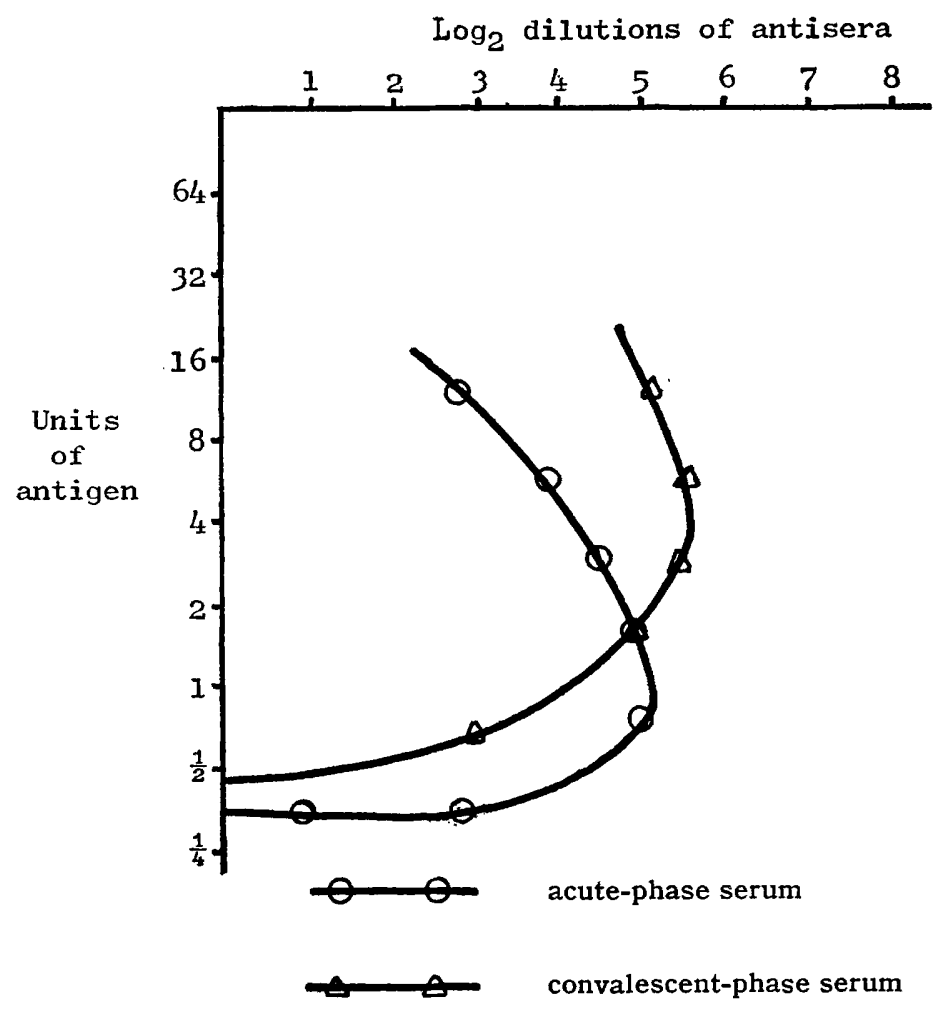

FIG. 3.-Differentiation between actively and passively acquired antibody by fixation patterns in a 5 -wk-old infant with a respiratory infection.

in the CF test. If this were so, it might also be possible to distinguish between actively and passively acquired antibodies in paired serum samples from single individuals. Such a possibility was tested in all infants under the age of $4 \mathrm{mth}$ in whom detectable amounts of CF antibody had been found in the acute-phase serum.

Out of 18 serum pairs that fell into this category, six showed the same fixation pattern in both acute- and convalescent-phase specimens. Five out of the six serum pairs had patterns characteristic of maternal antibody, together with a confirmatory decline in antibody titre in each case. In the sixth pair, both specimens showed patterns characteristic of actively acquired antibody, 
confirming an RS virus infection in this patient that had been diagnosed serologically during a previous hospital admission.

Three out of the 18 serum pairs gave equivocal results with regard to diagnosis, since all showed maternal antibody patterns in acute-phase sera and an absence of detectable antibody in convalescent-phase sera.

TABLE

Differentiation of actively and passively acquired antibodies to $R S$ virus by complement fixation $(C F)$ in paired sera from infants

\begin{tabular}{|c|c|c|c|c|c|c|c|}
\hline \multicolumn{2}{|c|}{ Patients } & \multicolumn{6}{|c|}{ Sera } \\
\hline \multirow[b]{2}{*}{ Number } & \multirow[b]{2}{*}{$\begin{array}{c}\text { Age } \\
(w k)^{*}\end{array}$} & \multirow[b]{2}{*}{$\begin{array}{l}\text { Day of } \\
\text { collection }\end{array}$} & \multirow{2}{*}{$\begin{array}{l}\text { Optimum } \\
\text { amount of } \\
\text { antigen for } \\
\text { CF (units) }\end{array}$} & \multirow{2}{*}{$\begin{array}{l}\text { Ratio: } \\
\text { maximum/ } \\
\text { optimum } \\
\text { titre of } \\
\text { antigen } \\
\text { for } \mathrm{CF}\end{array}$} & \multicolumn{2}{|c|}{$\begin{array}{l}\text { Titre of CF } \\
\text { antibody }\end{array}$} & \multirow[b]{2}{*}{$\begin{array}{l}\text { Antibody } \\
\text { pattern } \|\end{array}$} \\
\hline & & & & & $\begin{array}{l}\text { with low } \\
\text { dose } \$ \text { of } \\
\text { antigen }\end{array}$ & $\begin{array}{l}\text { with high } \\
\text { dose§ of } \\
\text { antigen }\end{array}$ & \\
\hline 1 & 2 & $\begin{array}{r}5 \\
37\end{array}$ & $\begin{array}{c}1 \frac{1}{2}-2 \\
8\end{array}$ & $\begin{array}{r}2 \\
\geq 8\end{array}$ & $\begin{array}{l}16 \\
\cdots\end{array}$ & $\begin{array}{r}6 \\
16\end{array}$ & $\begin{array}{l}\mathbf{P} \\
\mathrm{A}\end{array}$ \\
\hline 2 & 3 & $\begin{array}{r}5 \\
50\end{array}$ & $\frac{1 \frac{1}{2}}{6}$ & $\begin{array}{r}<2 \\
8\end{array}$ & $\begin{array}{l}48 \\
\ldots\end{array}$ & $\begin{array}{l}32 \\
32\end{array}$ & $\begin{array}{l}\mathbf{P} \\
\mathrm{A}\end{array}$ \\
\hline 3 & 4 & $\begin{array}{r}3 \\
45\end{array}$ & $\geqq 6^{1 \frac{1}{2}}$ & $\begin{array}{l}39 \\
\geqq 8\end{array}$ & $\begin{array}{l}64 \\
\cdots\end{array}$ & $\begin{array}{l}48 \\
96\end{array}$ & $\begin{array}{l}\mathbf{P} \\
\mathrm{A}\end{array}$ \\
\hline 4 & 5 & $\begin{array}{r}4 \\
34\end{array}$ & $\geqq 6^{1 \frac{1}{2}}$ & $\begin{array}{r}2 \\
\geqq 8\end{array}$ & $\begin{array}{l}48 \\
\cdots\end{array}$ & $\begin{array}{l}32 \\
96\end{array}$ & $\begin{array}{l}\mathrm{P} \\
\mathrm{A}\end{array}$ \\
\hline 5 & 5 & $\begin{array}{r}5 \\
44\end{array}$ & $\begin{array}{l}1 \\
4\end{array}$ & $\begin{array}{l}3 \\
8\end{array}$ & $\begin{array}{l}32 \\
\ldots\end{array}$ & $\begin{array}{l}24 \\
48\end{array}$ & $\begin{array}{l}\mathrm{P} \\
\mathrm{A}\end{array}$ \\
\hline 6 & 7 & $\begin{array}{l}16 \\
28\end{array}$ & $\geqq 6^{1 \frac{1}{2}}$ & $\begin{array}{r}3 \\
\geqq 8\end{array}$ & $\begin{array}{l}24 \\
\cdots\end{array}$ & $\begin{array}{l}16 \\
48\end{array}$ & $\begin{array}{l}\mathrm{P} \\
\mathrm{A}\end{array}$ \\
\hline 7 & 8 & $\begin{array}{r}2 \\
57\end{array}$ & $\geqq 6^{1 \frac{1}{2}}$ & $\begin{aligned} & 39 \\
\geqq & 8\end{aligned}$ & $\begin{array}{l}32 \\
\ldots\end{array}$ & $\begin{array}{l}16 \\
96\end{array}$ & $\begin{array}{l}\mathrm{P} \\
\mathrm{A}\end{array}$ \\
\hline 8 & 9 & $\begin{array}{r}5 \\
33\end{array}$ & $4^{1 \frac{1}{2}}$ & $\begin{array}{r}3 \\
\geqq 8\end{array}$ & $\begin{array}{l}48 \\
\cdots\end{array}$ & $\begin{array}{l}24 \\
32\end{array}$ & $\begin{array}{l}\mathrm{P} \\
\mathrm{A}\end{array}$ \\
\hline 9 & 10 & $\begin{array}{r}4 \\
34\end{array}$ & $\begin{array}{c}1 \frac{1}{2}-2 \\
4\end{array}$ & $\begin{array}{l}<2 \\
\geqq 8\end{array}$ & $\begin{array}{l}16 \\
\ldots\end{array}$ & $\begin{array}{l}12 \\
48\end{array}$ & $\begin{array}{l}\mathrm{P} \\
\mathrm{A}\end{array}$ \\
\hline
\end{tabular}

* At onset of infection; + after onset of infection.

$\$$ Optimum amount of antigen as determined with acute-phase serum.

$\S$ Optimum amount of antigen as determined with convalescent-phase serum.

$\mathbf{P}=$ Passive; $\mathbf{A}=$ active; $\uparrow$ estimated.

The remaining nine serum pairs showed a maternal antibody pattern in the acute-phase serum and an actively acquired antibody pattern in the convalescentphase serum. One typical result is shown in fig. 3 .

The results obtained with these nine serum pairs are summarised in the table; the data for fig. 3 were contributed by patient no. 5 . 
In addition to the maternal antibody patterns exhibited by the acute-phase sera in the last group of nine serum pairs, these sera also showed a characteristic low antigen requirement. In only two cases (patients no. 1 and 9) was the optimal requirement above $1 \frac{1}{2}$ units and it was still less than 2 units, and there was no correlation between the increased antigen requirement and the timeinterval from the onset of disease to the taking of the serum sample. In patient
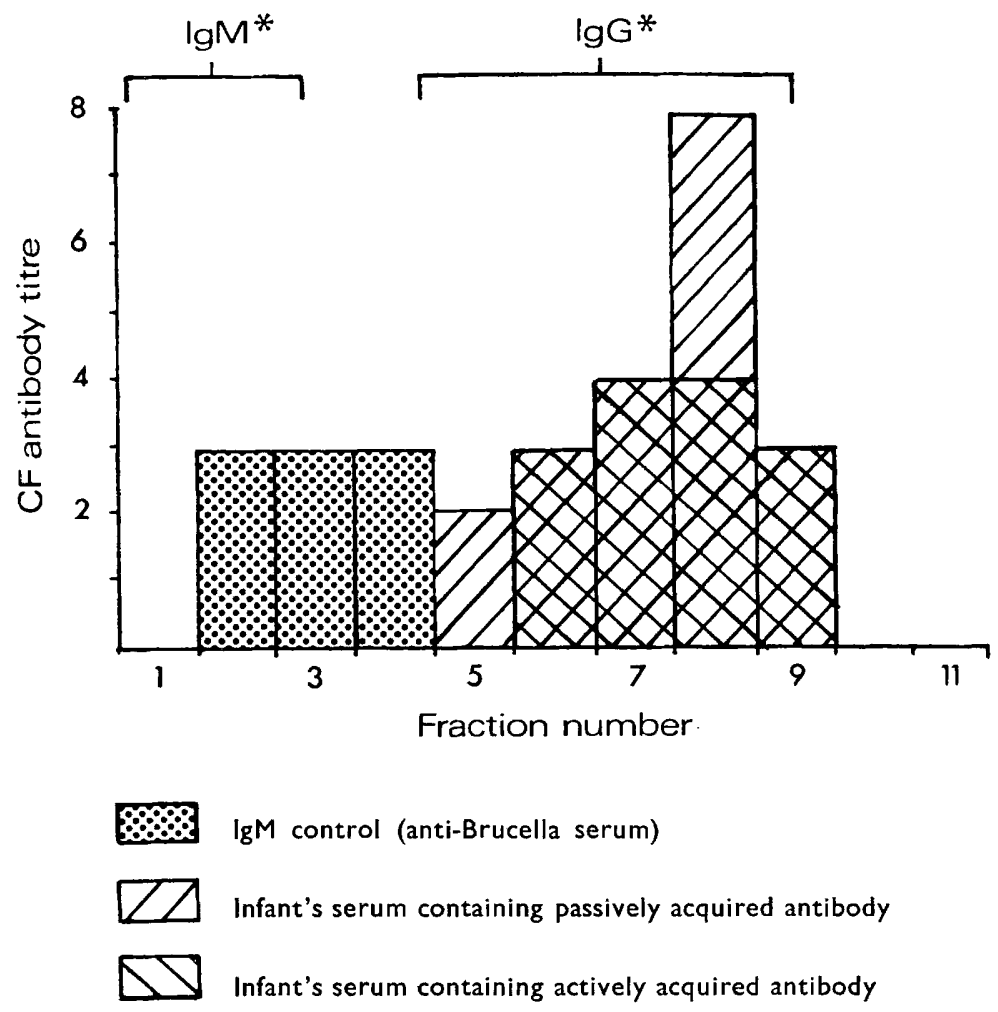

* Expected range deduced from results of Vesikari and Vaheri (1968).

FiG. 4.-Distribution of complement-fixing antibodies in a sucrose-density gradient.

no. 6 , several samples were examined, and in the first 16 days after onset only maternal antibody was found.

By contrast, all the convalescent-phase sera in this group showed the high antigen requirement for optimal fixation, and the high ratio of maximum to optimum titre of antigen, characteristic of actively acquired antibody in infants. None of the sera gave fixation patterns intermediate between the adult and infant antibody patterns.

The titres of the convalescent sera were not low, but even so four-fold rises were demonstrable in only two patients (no. 7 and 9) even with the optimum amount of antigen for the convalescent serum. With any smaller amount of 
antigen the titre of the acute specimen is increased, whilst that of the convalescent specimen is decreased (see figs. 1 and 2), thereby reducing the apparent rise in titre. However, in all nine patients in this group, a serodiagnosis of RS infection could be made by detecting actively acquired antibody in the convalescent-phase sera. The diagnosis was confirmed in three patients (no. 1, 8 and 9) by the isolation of the virus. It was also supported in seven out of nine patients by clinical evidence of bronchiolitis or bronchopneumonia; in the remaining two (no. 2 and 6) signs of acute chest infection had been present for 2 and 11 days respectively.

Out of 47 infants under the age of $4 \mathrm{mth}$ admitted to hospital with acute respiratory infections a diagnosis of RS virus infection was made in 19 (40 per cent.) by demonstrating a four-fold rise in antibody titre in the $\mathrm{CF}$ test with 8 antigen units. An additional 7 (15 per cent.) were diagnosed by differentiating infant and maternal types of antibody. Thus RS virus infections could be diagnosed serologically in over half ( 55 per cent.) of the infants in this age group, a figure that compares favourably with that of 43 per cent. obtained with 53 infants aged $4 \mathrm{mth}$ or more.

\section{Characterisation of antibodies}

High and low molecular weight antibodies were separated in several infants' sera by sedimentation in sucrose density gradients. CF antibody to RS virus antigen was found only in the IgG fraction. The result obtained with one serum is shown in fig. 4. The antibody class was confirmed by testing each fraction for resistance to reduction by 2-mercaptoethanol and by exclusion chromatography on Sephadex G-200. We concluded that fixation occurred only with the IgG fraction.

\section{Discussion}

A striking similarity was observed between the fixation patterns obtained with a pooled standard serum from adult females and certain infants' sera. Since this pattern was present in acute-phase serum samples of the very young it seemed evident that it was due to passively acquired maternal antibody. Successive samples of serum from uninfected infants showed a declining level of antibodies to RS virus and the pattern of fixation with respect to antigen requirement remained constant.

Once an infant became infected with RS virus a fixation pattern developed that differed from that seen with the standard serum, particularly in that such sera required 4-8 units of antigen for optimal fixation. Similar observations have been made previously by Ross et al. (1964) regarding antigen requirement. High CF antigen requirement by infants' and children's sera has also been reported for influenza (Lush and Burnet, 1937; Grist, 1957), for parainfluenza (Chanock and Johnson, 1964), and for Herpesvirus hominis infections (Ross, Russell and Wildy, 1964-65). In the last example quoted it was emphasised that the critical factor was not so much the age of the patient as whether the infection was primary or recurrent. The same observation has been made in cases of 
typhus due to Rickettsia prowazeki (Fox, Jordan and Gelfand, 1957; Murray et al., 1965a, $b$ and $c$ ). In addition there have been several reports of early CF antibody after a primary infection having a higher antigen requirement than later CF antibody. Most of these observations relate to rickettsial infections (Berge and Lennette, 1953; Hersey, Colvin and Shepard, 1957; Murray et al., 1965a), and it is perhaps significant that these are often chronic, or at least longlasting, infections, during which the host might be expected to produce antibodies characteristic of both early and late responses. On this basis it would seem reasonable to conclude that the high antigen requirement of infants' convalescent sera was due to the primary nature of the infection rather than to considerations of age and immunological maturity (Gardner, Elderkin and Wall, 1964; Janeway, 1966).

It has been suggested that the qualitative difference observed between infant (primary) and adult (secondary) CF antibody to RS virus is that the former is IgM (Ross et al., 1964). This conclusion was based on the reported sequence of IgM and IgG antibody formation in man (see Eichenwald, McCracken and Kundberg, 1967). As Humphrey and Dourmashkin (1965) had shown that IgM is a much more effective haemolytic agent than IgG it seemed reasonable to assume that IgM also fixes complement more effectively. Such a viewpoint receives confirmation from the suggestion of Borsos and Rapp (1965) that each molecule of IgM that is attached to the red cell surface can " fix " $\mathrm{C}^{\prime} 1$ and so initiate the lytic sequence, whereas it may take two molecules of IgG in the correct orientation to achieve the same result. Consequently, many more than twice as many molecules of IgG as of IgM would be needed to initiate complement fixation, or lysis.

However, the relevance of such data to the measurement of complement fixation is called into question by the work of Goodman (1959) and Goodman and Masaitis (1960), who showed that haemolytic efficiency was not paralleled by $\mathrm{CF}$ activity, and that the ratio of $\mathrm{CF}$ activity to haemolytic activity was some seven times greater for IgG than IgM. Nevertheless, direct comparison of the relative efficiency in fixing complement at the molecular level is not possible from the available data. Other workers have also examined the performance of immunoglobulin fractions in a variety of serological reactions. For instance, Dolby and Dolby (1969) examined the bactericidal activity of IgG and IgM preparations towards Bordetella pertussis. Although the protein concentrations of their fractions are given, their starting material consisted of hyperimmune serum, which might be expected to contain little in the way of specific $\operatorname{IgM}$, even within the IgM fraction. The same limitations apply to the data of Heremans, Vaerman and Vaerman (1963), which are sometimes quoted in support of the thesis that IgG fixes complement more efficiently than IgM.

However, Hornsleth (1968) has reported that complement-fixing activity was found only in the IgG fraction, obtained by exclusion chromatography, of serum from a 4-yr-old child convalescing from an RS virus infection. Similarly in this paper we report fixation with IgG, but not with IgM fractions; and indirect confirmation comes from the observation that sera taken 4-6 wk after infection contain higher titres of CF antibody than sera taken earlier 
(Ross et al., 1964). In addition, Wiedermann, Reinhardt and Kunz (1963) with an arbovirus and, more recently, Schmidt, Lennette and Dennis (1968) with coxsackieviruses, and Best, Banatvala and Watson (1969) with rubella and influenza viruses, have shown that human $\operatorname{IgG}$ fixes complement whereas the corresponding IgM does not.

In the face of mounting evidence that IgG but not IgM antibodies are involved in complement fixation, at least with viral antigens, we are forced to consider other possibilities, such as the specificities of antigens and antibodies taking part in the reaction, and the avidity of antibody, in order to explain differences in serological behaviour between maternal and infant IgG.

The nature of the antigen preparation itself might be important, since not all preparations behave in the same way. The antigens we have used show welldefined fixation optima, each with a zone of partial inhibition of fixation in the region of antigen excess. This region is not present with all preparations (see for example Ross et al., 1964). Also where there are sharp antigenic differences between strains, as with Rickettsia burneti, some antigens react only with late or secondary antibodies that have a specificity broader than that of first-formed antibody (Berge and Lennette). However, strain differences between RS viruses have not been detected in the CF test with human or animal sera (Wulff et al., 1964).

Heterogeneity of antibody response might also be due to the presence of different antigens on the same virus particle. If the proportion of antibodies directed against certain antigenic components differed consistently between adults and infants, this might account for differences in fixation patterns obtained with their sera. However, fractionation of several antigen preparations by exclusion chromatography indicated that the proportion of antibodies against antigens A and B of RS virus (Forsyth, Coates and Chanock, 1966) was the same in both infants and adults (Jacobs, unpublished).

Relatively much less is known about the role of avidity in complement fixation. In general, the first-formed antibody is of low avidity (Pike, 1967; Svehag, 1967), and because of its relatively high dissociation constant would perhaps require a higher proportion of antigen for maximum fixation. The reactions involved are, however, very complex and such an explanation to some extent begs such questions as whether complement itself, or some of its components, stabilises antigen-antibody reactions, whether such reactions are stabilised by time, and whether the time allowed for fixation allows maximum fixation under all conditions of avidity.

\section{Differentiation of actively and passively acquired antibodies in serum pairs}

In 15 out of 18 young infants, with complement-fixing antibody in the first serum sample, comparison of the fixation pattern in paired sera gave a clear differentiation between actively and passively acquired antibody. In the three other cases there was no detectable antibody in the second specimen, which might have been due to "mopping-up" of maternal antibody by infecting 
virus (Baum, 1968), to abnormally high rates of catabolism of maternal antibody (Janeway and Rosen, 1966), or to transient agammaglobulinaemia (Holborow, 1968).

In 9 out of the 18 pairs a change from the maternal to the infant type of fixation was indicative of RS virus infection. In some cases the change was less marked than in others, possibly owing to the presence of maternal antibody, which might either still be present in the convalescent serum or might have interfered with the immunological response of the infant (Evans and Smith, 1963; Dixon, Jacot-Guillarmod and McConahey, 1967; Eichenwald et al.). However, in all the cases studied, the shift in antigen optimum from 1-2 units in the acute-phase sera to 4-8 units in the convalescent-phase sera was a consistent indication of infection with RS virus, which was confirmed by virus isolation or clinical appraisal.

These findings have a limited application in the routine serodiagnosis of RS virus infections, partly because of the difficulty of obtaining serum samples 4-6 wk after the first samples, and partly because of the cumbersome nature of the block titration procedure. However the results were of interest, both with regard to the role of passively acquired antibody in primary infections (Chanock et al., 1967; Chanock et al., 1968), and to the possibility that two distinct kinds of antibody, both of which may be IgG, are formed in response to infection with RS virus. Whether this is an example of a general phenomenon is uncertain, but Riggs and Brown (1962) also noted a difference in serological behaviour between maternal and infant antibodies to poliovirus.

\section{SUMMARY}

The complement-fixing antibody formed by infants in response to a primary RS virus infection has a different fixation pattern, with a higher antigen requirement, than antibody present in adult serum and maternal antibody in the serum of infants. Differentiation between actively and passively acquired antibodies in paired sera from single infants enabled serodiagnoses to be made in cases where the presence of maternal antibody would otherwise have obscured the development of the infant's own antibodies. Possible reasons for the differences in fixation pattern are discussed.

The financial support for one of us (J. W. J.) by the Medical Research Council during the work reported is gratefully acknowledged.

\section{REFERENCES}

BAUM, S. G. . . . . . . . . . . 1968.

Berge, T. O., AND Lennette, E. H. . . 1953.

Best, Jennifer M., Banatvala, J. E., AND 1969. WATSON, D.

Borsos, T., AND RaPP, H. J. . . . . . 1965.

Chanock, R. M., AND Johnson, K. M. . 1964.
Perspect. Virol., 6, 138.

Amer. J. Hyg., 57, 144.

Lancet, 2, 65.

Science, N.Y., 150, 505.

In Diagnostic procedures for viral and rickettsial diseases, 3 rd ed., edited by E. H. Lennette and Nathalie J. Schmidt, New York, p. 481. 
Chanock, R. M., Kim, H. W., Vargosko, A. J., Deleva, Ann, Johnson, K. M., Cumming, Christine, and Parrott, R. H.

Chanock, R. M., Parrott, R. H., KAPIKIAN, A. Z., KIM, H. W., AND BrandT, C. D.

Chanock, R. M., Smith, C. B., FriedeWald, W. T., Parrott, R. H., Forsyth, B. R., Coates, H. V., Kapikian, A. Z., AND GHARPURE, M. A.

Dixon, F. J., Jacot-Guillarmod, H. and MCCONAHEy, Patricia J.

DOLbY, JeAN M., AND DOLBY, D. E.

Eichenwald, H. F., MCCracken, G. H., AND KundBerg, SHIRLEY J.

Evans, D. G., AND SMIth, J. W. G. . .

Forsyth, B. R., Coates, Helen V., and CHANOCK, R. M.

Fox, J. P., Jordan, Martha E., AND GELFAND, H. M.

Fulton, F.

GARDNER, P. S., ELDERKIN, $\dot{\mathrm{F}} \dot{\mathrm{M}}$. WALL, A. H.

GOODMAN, H. S.

Goodman. H. S., and Masaitis, Lillian

GRIST, N. R.

Grist, N. R., Ross, Constance A. C., Bell, E. J., AND Stott, E. J.

Heremans, J. F., Vaerman, J. P., and VAERMAN, C.

Hersey, D. F., Colvin, Mayme C., AND SHEPARD, C. C.

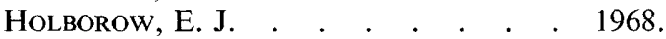

Hornsleth, A. . . . . . . . . . . 1968.

HUMPhrey, J. H., AND DOURMaShKin, 1965. R. R.

JACOBS, J. W.

JANEWAY, C. A.

1968.

1969.

1966.

JANEWAY, C. A., AND Rosen, F. S. . . 1966.

Kapikian, A. Z., Bell, J. A., Mastrota, F. M., JohnSON, K. M., HuEbner, R. J., AND CHANOCK, R. M.

Lush, DORA, AND BuRNET, F. M.

Murray, E. S., Gaon, J. A., O'Connor, JaNe M., aND Mulahasanovic, M.

Murray, E. S., O'Connor, Jane M., AND GAON, J. A.
J. Amer. Med. Assoc., 176, 647.

Perspect. Virol., 6, 125.

In I Int. Conf. on vaccines against viral and rickettsial diseases of man. PanAm Hith Org. Scientific Publn no. 147, p. 53.

J. Exp. Med., 125, 1119.

Immunology, 16, 737.

Prog. Med. Virol., 9, 35.

Br. Med. Bull., 19, 225.

J. Bact., 91, 1270.

J. Immun., 79, 348.

Adv. Virus Res., 5, 247.

Br. Med. J., 2, 1570.

J. Infect. Dis., 105, 69.

J. Immun., 85, 391.

Scott. Med.J., 2, 249.

In Diagnostic methods in clinical virology, Oxford, p. 58.

J. Immun., 91, 11.

Ibid., 79, 409.

An $\mathrm{ABC}$ of modern immunology, London, p. 27.

Acta path. microbiol. scand., 74, 458.

In Complement (Ciba Fdn Symp.), ed. by G. E. W. Wolstenholme and Julie Knight, London, p. 175.

Lab. Pract., 17, 1338.

Ibid., 18, 443.

Archs Dis. Child., 41, 358

New Engl. J. Med., 275, 826.

Amer. J. Hyg., 74, 234.

1937. Austral. J. Exp. Biol. Med. Sci., 15, 375.

1965a. J. Immun., 94, 723.

1965b. Ibid., 94, 734.

1965c. Proc. Soc. Exp. Biol. Med., 119, 291. 
Parrott, R. H., Vargosko, A. J., Kim, 1961. J. Amer. Med. Assoc., 176, 653.

H. W., Cumming, Christine Turner,

H., Huebner, R. J., AND Chanock,

R. M.

Pike, R. M.

1967. Bact. Rev., 31, 157.

RigGS, J. L., AND Brown, G. C. . . . 1962. J. Immun., 89, 868.

Ross, Constance A. C., Stott, E. J., 1964. Arch. ges. Virusforsch., 14, 553.

MCMichael, S., AND Crowther, I. A.

Ross, Constance A. C., Russell, W. C., 1964-65. Ibid., 15, 58.

AND WILDY, P.

Schmidt, Nathalie J., Lennette, E. H., $1968 . \quad$ J. Immun., 100, 99. AND DENNIS, J.

SveHAG, S-E. . . . . . . . . 1967. In Antibodies to biological active molecules, ed. by B. Cinader, Oxford, p. 301.

Vesikari, T., AND VAHERI, A. $\quad$. . . $\quad 1968 . \quad B r . M e d . J ., 1,221$.

Wiedermann, G., Reinhardt, F., and 1963. Zentbl. Bakt. ParasitKde, Abt. I, Orig. KunZ, C. 189, 15.

Wulff, H., Kidd, Patricia, and 1964. Proc. Soc. Exp. Biol. Med., 115, 240. WENNER, H. A. 